\title{
The Role of Snails and Ants in Transmitting the Avocado Stem Canker Pathogen, Phytophthora citricola
}

\author{
Zeinab A. El-Hamalawi and John A. Menge \\ Department of Plant Pathology, University of California, Riverside, CA 92521
}

Additional index words. Persea americana, Persea indica, Helix aspersa, Iridomyrmex humilis

\begin{abstract}
The sugary exudate appearing on bark lesions of Persea americana Miller and Persea indica plants after infection with Phytophthora citricola contained viable oospores and hyphal fragments in the field and in the greenhouse. This sugary exudate was a source of inoculum and dispersal of the pathogen within and between avocado plants. Spraying water onto lesions moved inoculum from the sugary exudate to wounds below. Water from sprinkler irrigation washed propagules into the soil around the plants. Viable propagules of Phytophthora citricola were identified in the feces of snails (Helix aspersa) that had fed on infected bark tissues. When these snails were moved to healthy plants, they made wounds on succulent tissue, and the infectious feces induced cankers. Ants (Iridomyrmex humilis) were attracted to the sugary exudate and also transmitted infectious propagules to wounds on avocado stems and to the soil. Control strategy for the avocado stem canker disease should consider control of vectors.
\end{abstract}

In California, a severe stem canker disease of avocado (Persea americana), caused by Phytophthora citricola Sawada, has spread to all major avocado growing areas (Coffey, 1987). Phytophthora citricola affects the crown, lower trunk, and sometimes the main structural roots (Coffey, 1987; Zentmyer et al., 1973; Zentmyer et al., 1974). Phytophthora citricola acts mainly as a wound pathogen (El-Hamalawi and Menge, 1994a, 1994b) that usually invades wounded host tissue at or near the soil line and causes a canker in the inner bark tissue, which may be lethal to the tree, if not arrested. In advanced stages, defoliation and twig dieback occur. Phytophthora citricola attacks mature trees and also causes collar rot in young nursery trees (Coffey and Cohen, 1984).

Understanding the sources of inoculum and the dispersal mechanism of any pathogen is important to develop effective control measures. Little is known about either the short or long-range spread of the stem canker disease of avocado or the dispersal of its causal agent. Dispersal mechanisms of most Phytophthora species such as Phytophthora palmivora, causing black pod of cocoa, Phytophthora nicotianae, causing black shank of tobacco, Phytophthora infestans, causing potato late blight, and Phytophthora cinnamomi, causing avocado root rot, are closely or directly related to the movement of water.

Insects are not usually viewed as vectors of Phytophthora. However, transmission of Phytophthora species has been reported for a number of insects such as Sciara flies (Murphy and McKay, 1927), Drosophila (Hunter and Buddenhagen, 1969), the weevil Scyphophorus interstitialis Gyll., and ants (McGregor and Moxon, 1985; Newhook and Jackson, 1977; Okaisabor, 1974; Peregrine, 1969; Taylor and Griffin, 1981; Turner, 1972). Snails have also been shown to be vectors of Phytophthora (Kueh and Khew, 1982; Turner, 1964).

Sugary exudates are associated with stem canker development in avocado trees that are infected with Phytophthora citricola. Snails, ants, Drosophila, and other insects are common in avocado

Received for publication 4 May 1995. Accepted for publication 4 Apr. 1996. We thank G.A. Zentmyer and D.C. Erwin for reviewing the manuscript and we acknowledge the financial assistance of California Avocado Commission in this project. The cost of publishing this paper was defrayed in part by the payment of page charges. Under postal regulations, this paper therefore must be hereby marked advertisement solely to indicate this fact. groves and frequently are observed to be in contact with infected trunk cankers of avocado trees. There is little attempt at insect control in most California avocado orchards. Chemical control of mites, thrips, and loopers may be attempted, but biological control is more frequently practiced. The brown garden snail (Helix aspera Muller) is often a pest in avocado orchards and can be controlled with copper painted in bands around the base of the trees or by the introduced predatory decollated snail, Ruminia decollata Linn. The objective of this study was to determine if the sugary exudates from avocado stem cankers serve as a source of inoculum in avocado groves and the possible role of snails and ants as dispersal vectors of Phytophthora citricola to avocado plants.

\section{Materials and Methods}

Plant material. 'Topa Topa' avocado (Persea americana) plants were grown from seed in UC no. 4 soil mix (Matkin and Chandler, 1957) in plastic liners $(6 \times 12 \mathrm{~cm})$ with perforated bases for drainage. After 6 weeks of growth in a shaded greenhouse, seedlings were transplanted into 4-L pots containing the same soil mix. Plants of Persea indica Spreng., a close relative of avocado, which is more susceptible to Phytophthora citricola than Persea americana, were grown from seed in a flat of sand in the greenhouse. Forty-five days after sowing, seedlings were transplanted individually into 4 -L pots containing UC no. 4 soil mix. One-yearold Persea americana and Persea indica plants and stem cuttings $(20 \mathrm{~cm})$ from 1-year-old Persea indica plants were used in the study. Greenhouse temperatures fluctuated between 18 and $30^{\circ}$. Daytime photosynthetically active radiation averaged 157 $\mu \mathrm{mol} \cdot \mathrm{m}^{-2} \cdot \mathrm{s}^{-1}$. Two-year-old 'Hass' avocado (Persea americana) grafted on 'Barr Duke' or 'Topa Topa' rootstocks was used in lathhouse experiments. Lathhouse conditions closely resembled outdoor conditions with regard to temperature (average $27^{\circ} \mathrm{C}$ day/ $17^{\circ} \mathrm{C}$ night) and day length, although daytime light intensity was reduced $60 \%$ to about $104 \mu \mathrm{mol} \cdot \mathrm{m}^{-2} \cdot \mathrm{s}^{-1}$. Trees in the greenhouse and lathhouse were irrigated with dilute (14\%) Hoagland's solution (Tuite, 1969) as needed.

Preparation of inoculum and inoculation method. The isolate of Phytophthora citricola (cc-6) used in these studies was recovered originally from a canker on avocado near Temecula, Calif. The stock culture was maintained on slants of clarified V8C agar 
medium (per liter: Campbell V8 juice clarified by centrifugation, $200 \mathrm{~mL}$; $\mathrm{CaCO}_{3}, 2 \mathrm{~g}$; agar, $15 \mathrm{~g}$; deionized water, $800 \mathrm{~mL}$ ) and stored in the dark at $18^{\circ} \mathrm{C}$. Fresh cultures were grown on V8C agar dishes and incubated at $24^{\circ} \mathrm{C}$ in the dark. Phytophthora citricola was reisolated monthly from colonized bark tissue of avocado plants to maintain its virulence, and the identity of Phytophthora citricola was confirmed microscopically using the revised key of Stamps, et al. (1990).

Avocado plants were stem-inoculated by removing a 4-mmdiameter disc from the bark with a cork borer to expose the cambium and placing a V8C agar plug of similar size containing mycelium of Phytophthora citricola on the exposed cambium. The wound was moistened with a drop of water after inoculation and wrapped with a strip of Parafilm to prevent drying. Stem cuttings were inoculated at the middle section of each cutting and were incubated at $20^{\circ} \mathrm{C}$ in a moist chamber $(35 \times 22 \times 15 \mathrm{~cm})$. Two weeks after inoculation, samples of the infected bark were removed and incubated on PARPH agar (Mitchell et al., 1986) to detect Phytophthora citricola.

Sugary exudate as a source of Phytophthora citricola inoculum. Following inoculation of 2-year-old trees with Phytophthora citricola (above the graft union) at about $10 \mathrm{~cm}$ above the soil line in the lathhouse, an exudate of sugary material was associated with developing cankers. At the early stages of infection, the sugary material appeared as a viscous liquid (Fig. 1), which dried with time to form a powdery residue (Fig. 2). The liquid and dry sugary exudates were examined microscopically for Phytophthora citricola propagules. Samples of the liquid and the dry sugary exudate were placed on PARPH agar to detect Phytophthora citricola. Ten healthy greenhouse-grown avocado plants each of Persea americana and Persea indica and 10 stem cuttings of Persea indica were wounded (4-mm-diameter wound) as described above, and each wound was inoculated with $0.1 \mathrm{~g}$ of dry sugary exudate, moistened with 2 drops of water, and wrapped with a strip of Parafilm.

In a second experiment, 40 greenhouse-grown Persea americana plants were wounded and inoculated with Phytophthora citricola at about $130 \mathrm{~cm}$ above the soil line. Four weeks after inoculation, the cankers were covered with sugary exudates. Twenty of the infected plants were wounded again at about $10 \mathrm{~cm}$ above the soil line. In ten wounded and infected plants, stems above the sugary exudate sites were sprayed with sufficient water to run down the stems over the sugary exudate to the stem wounds. Ten wounded, infected plants were used as controls without water spray. The cut wounds were periodically examined for infection and the presence of Phytophthora citricola was verified on PARPH agar. Ten infected plants were watered using sprinklers directed towards the sugary exudate areas and another group of plants were watered by drip irrigation. Three soil samples collected from around the base of each plant of all groups were plated on PARPH agar to detect Phytophthora citricola using the soil dilution technique (Mitchell et al., 1986). All experiments were performed three times.

Transmission of Phytophthora citricola by ants. Ten Persea americana trees grown in the lathhouse were wounded and inoculated with Phytophthora citricola at about $130 \mathrm{~cm}$ above the soil line. Ants (Iridomyrmex humilis Mayr.) were attracted to the sugary material exuded by the cankerous tissue of the infected avocado trees. New wounds were made on the stems of ten Persea americana avocado trees, at about $10 \mathrm{~cm}$ above the soil line, along the path of the ants as they move downward away from the sugary exudate. For the control pots, 10 wounded, infected avocado trees were placed in a tray containing water to keep ants away from the plants. The formation of new cankers in the wound sites was determined. Fifteen to twenty ants that were collected with a sterile tweezer as they were moving away from the sugary exudate area were placed on PARPH agar to detect Phytophthora citricola. Twenty ants collected with a sterile tweezer were placed on wounds made on the stem of ten healthy Persea americana avocado plants (two ants/ wound) and wrapped with Parafilm. Two weeks later, the inoculation sites were evaluated for canker development.

About 50 ants (Iridomyrmex humilis) were collected from Phytophthora-infected avocado plants in the lathhouse by brushing them into containers with an artist's brush and were placed in an artificial colony. The artificial colony consisted of two 150mm-diameter $\times 30$-mm plastic petri dishes connected by Tygon tubing (30.5 $\mathrm{cm} \times 2.4 \mathrm{~mm}$ inside diameter). One petri dish served as a nest site and the other was a feeding arena (Fig. 3). Ants moved freely between the two dishes. The sugary exudate was placed in the second dish for feeding. After feeding on the sugary exudate, ants were transferred to a second artificial colony containing five wounded Persea indica stem cuttings in the feeding dish of the colony. Two artificial colonies were used for each experiment. Replicates containing five wounded Persea indica stem cuttings without ants served as the control. Wounds on the stem cuttings were examined for canker development and Phytophthora citricola was detected by isolation on PARPH agar. All experiments were performed three times.

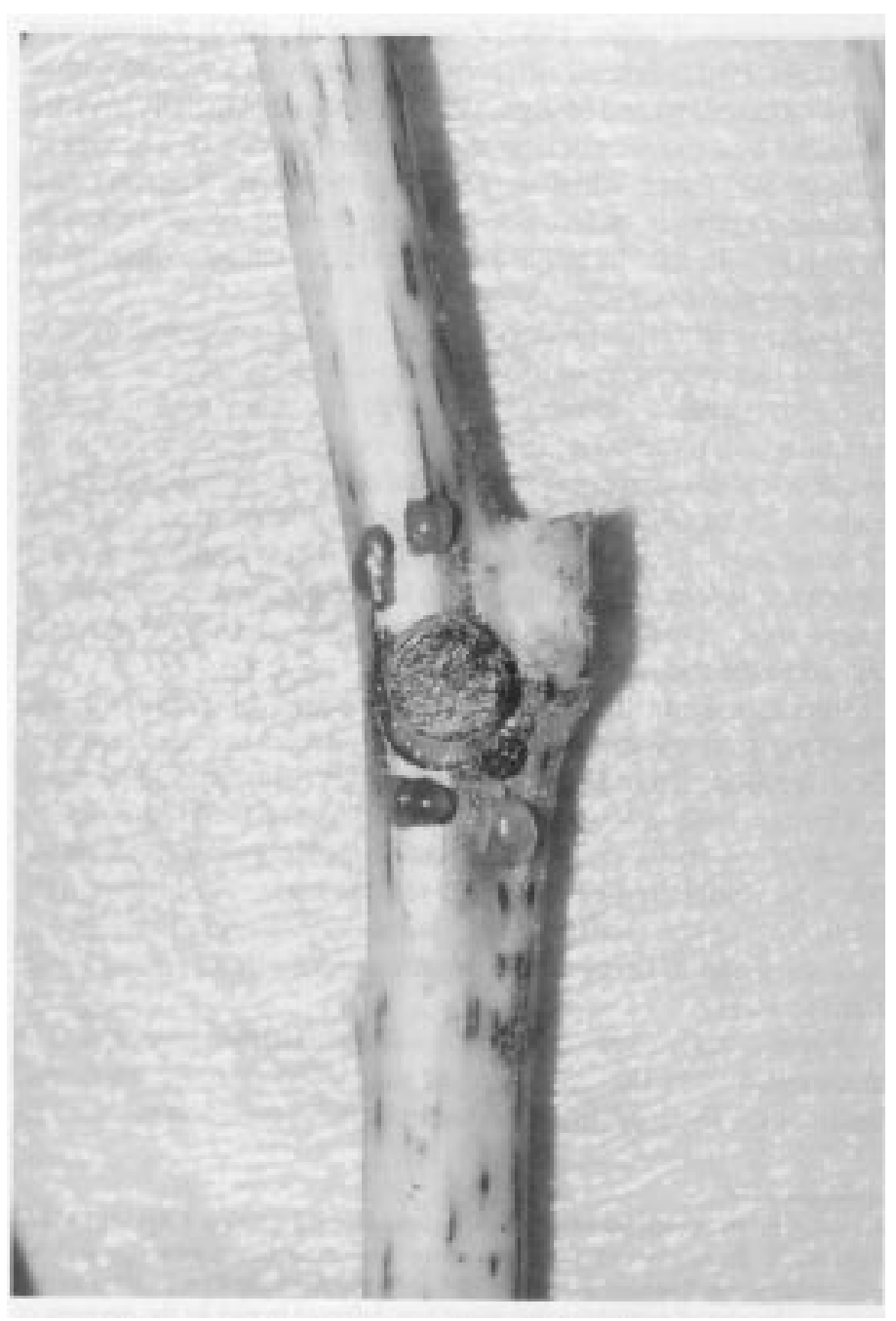

Fig. 1. Sugary material exuded as a viscous liquid from canker on avocado plants caused by Phytophthora citricola at the early stages of infection. 
Testing snails as vectors of Phytophthora citricola on avocado plants. Persea indica stem cuttings were inoculated with Phytophthora citricola as described above. After the cankers developed and covered the stem cuttings (about 10 days after inoculation), 10 brown garden snails (Helix aspera) were placed for 5 days in each moist chamber. Five moist chambers with 10 stem cuttings each were used in the study. Snails fed on noninoculated avocado stem cuttings were used as controls. After snails fed, they were washed twice with distilled water, dried, and placed in cages for collection of feces. Smears of the fresh fecal material were examined microscopically and samples were placed on PARPH agar to isolate and detect Phytophthora citricola. Samples of the moistened feces (about $0.2 \mathrm{~g} /$ wound) were also used to inoculate 10 Persea americana avocado plants in the greenhouse and 20 stem cuttings of Persea indica in moist chambers.

After inoculating 10 Persea americana avocado plants with Phytophthora citricola, cankers were left for a 2-week period to develop. Six brown garden snails (Helix aspersa) were placed in contact with each infected plant. Other snails were placed in contact with noninoculated plants. The pot and the lower $25 \mathrm{~cm}$ portion of the plant were covered with a plastic bag (perforated with small holes to allow aeration) to confine the snails that fed on the plants for 2 days. Snails fed on infected and noninfected plants were later removed, washed with distilled water, wiped dry with a

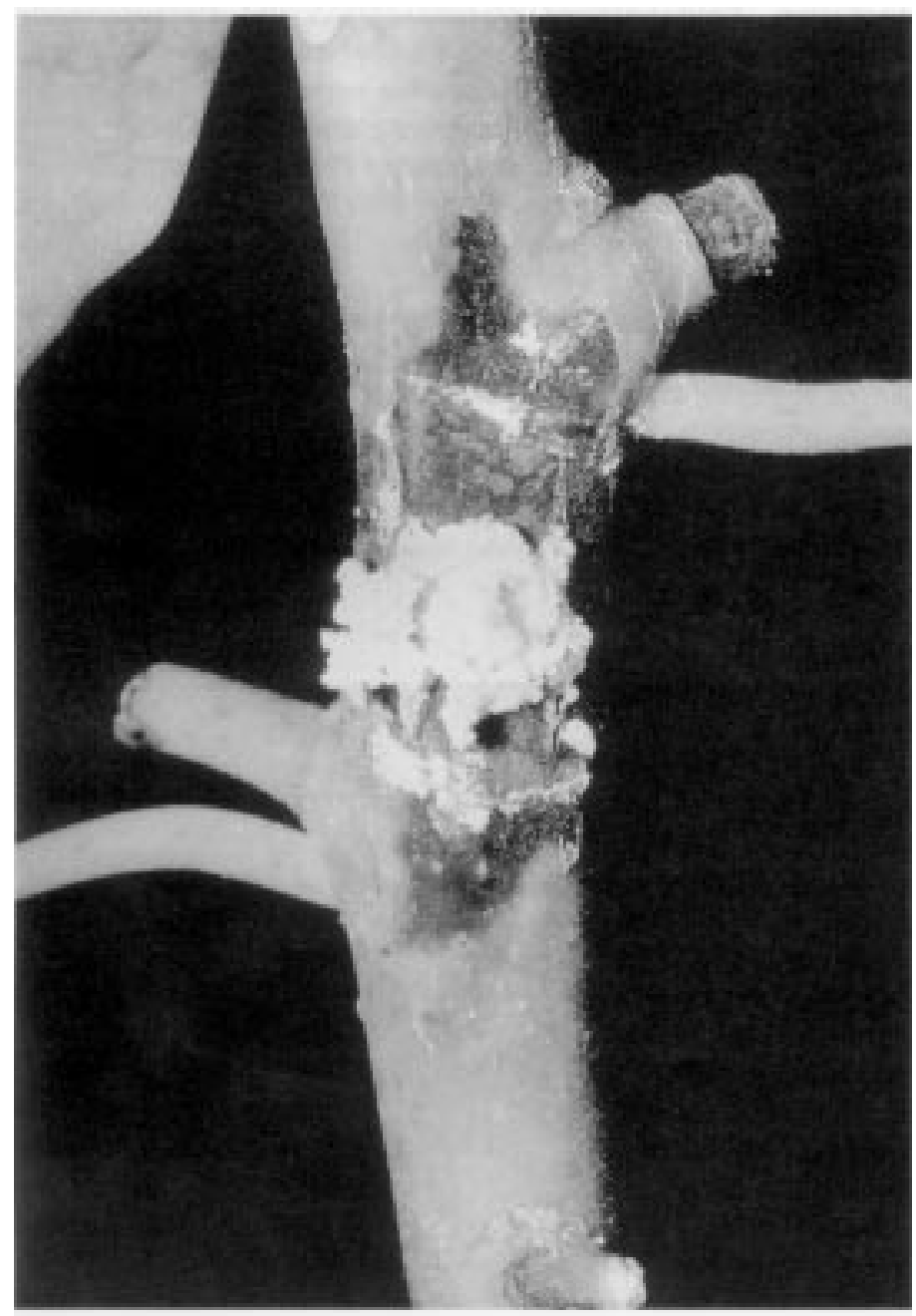

Fig. 2. Powdery sugary material formed after the drying of the sugary liquid exuded during canker development on avocado plants following infection by Phytophthora citricola. paper towel, and confined in contact with 10 unwounded, noninoculated Persea americana plants (three snails/plant) and 20 noninoculated Persea indica stem cuttings (two snails/cutting). Stem cuttings and potted plants were examined for the presence of cankers. Sections of cankers that formed on the bark were placed on PARPH agar to detect Phytophthora citricola. Three soil samples collected from around each plant were placed on PARPH agar to isolate and detect Phytophthora citricola. All experiments were performed three times.

In the field, snails were collected from around the base of the trunk of trees infected with Phytophthora citricola. Snails were washed with distilled water and placed in cages, and the feces were collected for microscopic examination. Samples of the feces were placed on PARPH agar to detect Phytophthora citricola. Samples of the feces were also used for inoculation of 10 Persea americana avocado plants in the greenhouse. Experiments were performed three times.

\section{Results}

Sugary exudate as a source of Phytophthora citricola inoculum. Microscopic examination of the liquid sugary exudate associated with the canker development caused by Phytophthora citricola (Fig. 1) revealed the presence of fungal oospores and hyphal fragments (Fig. 4), whereas the dry sugary (Fig. 2) material contained only oospores (Fig. 4). The identity of Phytophthora citricola was confirmed, since $100 \%$ of the isolations on PARPH agar yielded Phytophthora citricola. Placing the sugary exudate on stem wounds of Persea americana and Persea indica plants and wounded stem cuttings of Persea indica resulted in infection and canker formation in $90 \%, 100 \%$, and $100 \%$ of the sites inoculated, respectively. Phytophthora citricola was also identified in samples of the cankerous tissue. The sugary material that washed downward following spraying with water caused canker formation in $60 \%$ ( 18 out of 30 plants used in three experiments) of the wounded plants. After spraying infected plants with water or by using sprinkler irrigation, Phytophthora citricola was detected in $44 \%$ (80 out of 180 samples) of the soil samples. Phytophthora citricola was detected in $10 \%$ (18 out of 180 samples) of the soil samples of the nonsprayed and drip-irrigated plants. Over all experiments, replicate experiments were nearly identical.

Role of ants in transmitting Phytophthora citricola in avocado plants. Sixty percent (18 out of 30 in the three experiments) of the wounded sites made in avocado plants on which ants traversed between the sugary exudate of the canker and the soil line became infected with Phytophthora citricola. All of the ants feeding on the sugar exudate yielded Phytophthora citricola when they were plated on PARPH. In the absence of ants, wounds on the control plants did not become infected with Phytophthora citricola. When ants collected from the stems of infected avocado plants in the lathhouse were used as inoculum, $67 \%$ (20 out of the 30 plants used in the three experiments) of wound sites on avocado stems became infected. Ants that fed on the sugary exudate in artificial colonies carried Phytophthora citricola and caused 73\% (22 out of 30 stem cuttings used in three experiments) of the wounded stem cuttings to develop cankers. No cankers developed in wounded stem cuttings without ants. All isolations from cankers on PARPH agar confirmed the presence of Phytophthora citricola.

Role of snails as dispersal vectors of Phytophthora citricola to avocado plants. Oospores and hyphal fragments were microscopically detected in the feces of snails that fed on cankered avocado stem cuttings. Feces of the snails that were fed on either infected plants in the greenhouse or infected stem cuttings in moist cham- 


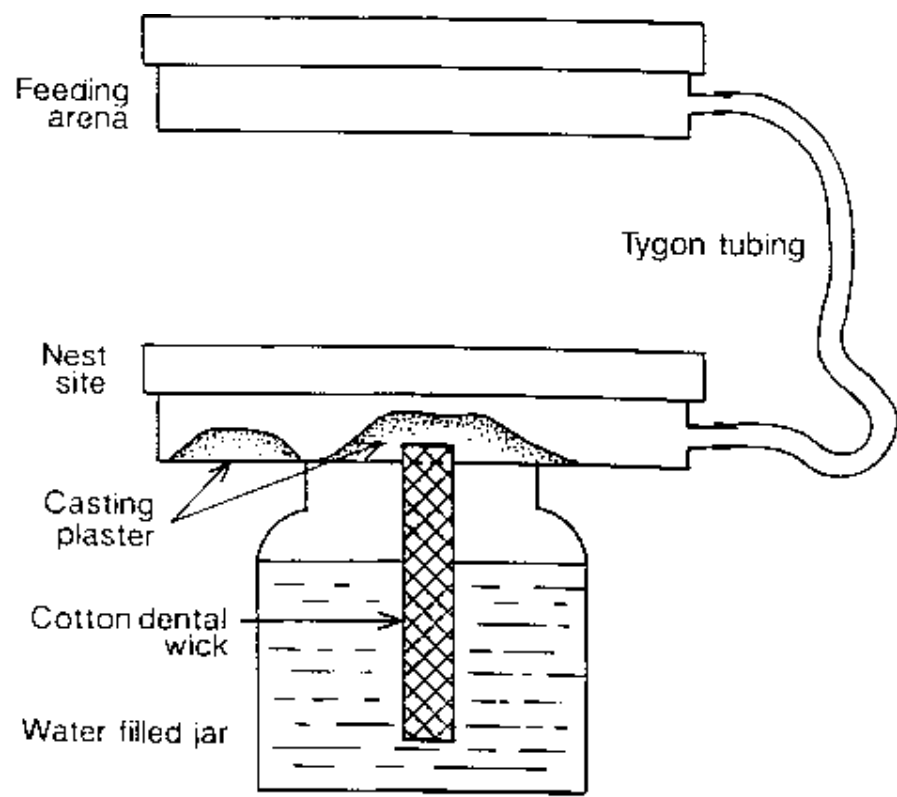

Fig. 3. An artificial ant colony that consisted of two 150 -mm-diameter $¥ 30 \mathrm{~mm}$ plastic petri dishes connected by a piece of Tygon tubing $(30.5 \mathrm{~cm} ¥ 2.4 \mathrm{~mm}$ inside diameter). One petri dish served as a nest site and the other was a feeding arena. Ants moved freely between the two dishes.

bers tested positive for the presence of Phytophthora citricola on PARPH agar. Placing feces of snails that were fed on cankered stem cuttings onto wounds caused infection and canker development in $77 \%$ (23 out of 30 plants in three experiments) of the Persea americana plants and $85 \%$ (51 out of 60 stem cuttings used in three experiments) of the Persea indica stem cuttings.

Snails which fed on infected Persea americana plants caused infection and canker development in $40 \%$ (12 out of 30 plants used in the three experiments) of the Persea americana plants and $55 \%$ (33 out of 60 stem cuttings used in the three experiments) of the Persea indica stem cuttings. Phytophthora citricola was detected in $100 \%$ of the newly developed cankers using PARPH agar. Eighty percent (72 out of 90 samples in three experiments) of the soil samples collected from the area around the trunks of Persea americana plants inoculated with Phytophthora citricola via snails yielded Phytophthora citricola on PARPH agar (Table 3).

Feces from snails collected from around the base of the trunk of Phytophthora citricola-infected avocado trees in the field tested positive for Phytophthora citricola on PARPH and were found to contain oospores and hyphal fragments of Phytophthora citricola. Inoculating Persea americana in the greenhouse with feces material from snails collected from field trees infected with Phytophthora citricola resulted in infection of $60 \%$ (18 out of 30 plants used in the three experiments) of the Persea americana plants.

\section{Discussion}

The sugary material exuded by the Phytophthora citricolainfected stems of avocado trees (Figs. 1 and 2) was an important source of inoculum since it contained viable fungal oospores and mycelial fragments. The sugary exudate can be disseminated by rain or sprinkler irrigation to the soil or other wounded parts of the tree (El-Hamalawi and Menge, 1994a). Also, the dry sugary material was frequently observed to drop off the stem cankers and mix with the soil around the base of the tree, which contaminates the soil with Phytophthora citricola. Zoospores formed from oospores in water films can be transmitted throughout the tree, to other avocado trees, or to the soil surface by surface water after rain or sprinkler irrigation. Application of the fungicide fosetyl-Al as a paint on the canker is an effective method to prevent the sugary exudate from being an inoculum source for disease transmission. Recent results indicate that fosetyl-Al could cure the canker disease and eradicate Phytophthora citricola in the plant tissues (El-Hamalawi and Menge, 1994b).

Our observation in the field and the lathhouse indicated that ants (Iridomyrmex humilis) were attracted to the sugary exudate produced on developing cankers caused by the infection of avocado plants by Phytophthora citricola. Since the sugary exudate contained viable propagules such as oospores and hyphal fragments, these could be readily transmitted from one part of the tree to another. Ants may also transmit the inoculum from tree to tree or to the soil.

The feces of the snails collected from the field contained viable oospores and hyphal fragments of Phytophthora citricola, which indicates the possible importance of snails in spreading the stem canker disease in avocado groves. The presence of oospores and hyphae in the feces also confirmed that propagules of Phytophthora citricola are resistant to the digestive secretion of the snail. The fungus does not only survive inside the snails, but the inoculum potential may increase as it passes through the alimentary canal (Gregg, 1957). The passage of oospores of Phytophthora cactorum, Phytophthora erythroseptica and Phytophthora megasperma through the snails Planorbarius corneus (Linn.), Helix aspersa (Muller), and Eopania vermiculata (Multer) resulted in a high percentage of oospore germination (Gregg, 1957; Shaw, 1967). The passage of oospores of Phytophthora palmivora through the snail Cryptozona semirugata Beck. also resulted in a high percentage of oospore germination (Dutta et al., 1984; Kumari et al., 1988).

Since a considerable amount of inoculum was carried by snails and ants, these organisms may be important factors for the dispersal of Phytophthora citricola in avocado orchards and should not be ignored. It is possible that other insects and arthropods also may disperse inoculum of Phytophthora citricola in a similar manner in the field. Controlling snails and ants in the avocado groves should be included in the strategy for controlling the stem canker disease.

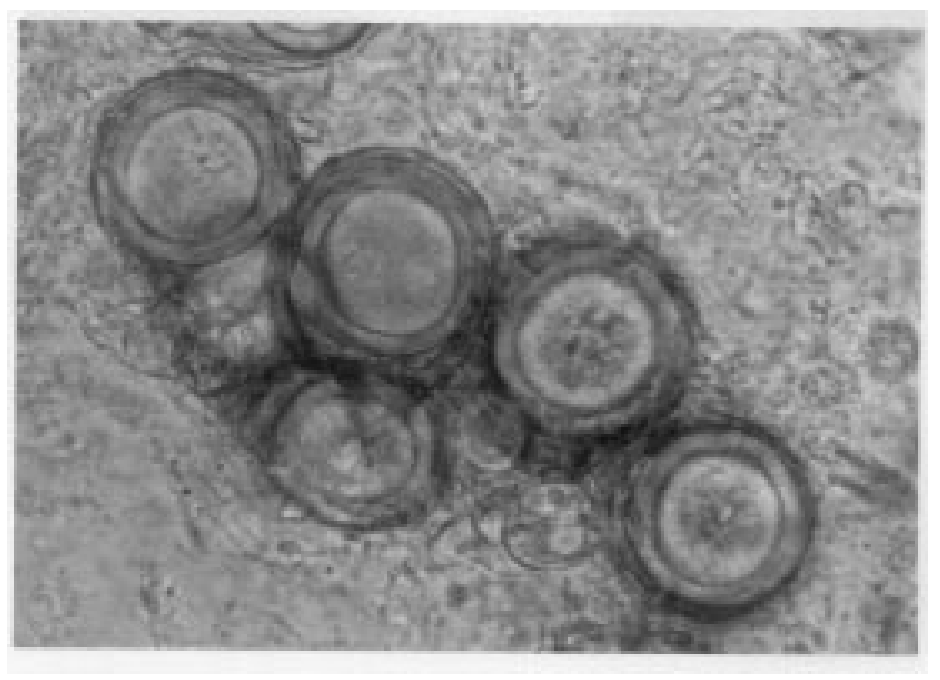

Fig. 4. Oospores and hyphal fragments of Phytophthora citricola found in the sugary material exuded during canker development after infection of avocado stems. 


\section{Literature Cited}

Coffey, M.D. 1987. Phytophthora root rot of avocado: An integrated approach to control in California. Plant Dis. 71:1046-1052.

Coffey, M.D. and Y. Cohen. 1984. Crown and collar rot of avocado: A need for more research. Calif. Avocado Soc. Yearbook. 68:69-74.

Dutta, P.K., R.K. Hedge, and K.H. Anahosur. 1984. An assured in vitro technique for the germination of oospores of Phytophthora palmivora (Butler) Butler. Current Sci. 53:655-656.

El-Hamalawi, Z.A. and J.A. Menge. 1994a. Avocado trunk canker disease caused by Phytophthora citricola: investigation of factors affecting infection and disease development. Plant Dis. 78:260-264.

El-Hamalawi, Z.A. and J.A. Menge. 1994b. Effect of wound age and fungicide treatment of wounds on susceptibility of avocado stems to infection by Phytophthora citricola. Plant Dis. 78:700-703.

Gregg, M. 1957. Germination of oospores of Phytophthora erythroseptica. Nature 180:150.

Hunter, J.E. and I.W. Buddenhagen. 1969. Field biology and control of Phytophthora parasitica on papaya (Carica papaya) in Hawaii. Ann. Appl. Biol. 63:53-60.

Kueh, T.K. and K.L. Khew. 1982. Survival of Phytophthora palmivora in soil after passing through alimentary canals of snails. Plant Dis. 66:897899.

Kumari, P.S., R.K. Hedge, P.W. Basarkar, C.N. Srinivasan, and S. Kalkarni. 1988. Role of enzymes in the gut region of the garden snail (Cryptozona semirugata Beck.) on the germination of the oospores of Phytophthora spp. Indian J. Plant Pathol. 6:49-51.

Matkin, O.A. and P.A. Chandler. 1957. The UC-type soil mixes, p. 68-85. In: K.F. Baker (ed.). The UC system for producing healthy containergrown plants. Calif. Agr. Expt. Sta. Ext. Serv.

McGregor, A.J. and J.E. Moxon. 1985. Potential for biological control of tent building species of ants associated with Phytophthora palmivora pod rot of cocoa in Papua New Guinea. Ann. Appl. Biol. 107:271-277.

Mitchell, D.J., M.E. Kannwischer-Mitchell, and G.A. Zentmyer. 1986. Isolating, identifying and producing inoculum of Phytophthora spp, p.
63-66. In: K.D. Hickey (ed.). Methods for evaluating pesticides for control of plant pathogens. Amer. Phytopathol. Soc., St. Paul, Minn.

Murphy, P.A. and R. McKay. 1927. Some further cases of the production of diseased shoots by potato tubers attacked by Phytophthora infestans, and a demonstration of alternative sources of foliage and tuber infection. Sci. Proc. Royal Dublin Soc., N.S. 18:413-422.

Newhook, F.J. and G.V.H. Jackson. 1977. Phytophthora palmivora in cocoa plantation soils in the Solomon Island. Trans. Br. Myc. Soc. 69:31-38.

Okaisabor, E.K. 1974. Phytophthora pod rot infections from the soil, p. 161-168. In: P.H. Gregory (ed.). Phytophthora disease of cocoa. Longman, London.

Peregrine, W.T.C. 1969. Investigations on chemical control of zebra disease in Agave hybrid no. 11648. Ann. Appl. Biol. 63:45-51.

Shaw, D.S. 1967. A method of obtaining single oospore cultures of Phytophthora cactorum using live water snails. Phytopathology 57:454.

Stamps, D.J., G.M. Waterhouse, F.J. Newhook, and G.S. Hall. 1990. Revised tabular key to the species of Phytophthora. Mycol. Papers 162. CMI, Kew, Surrey.

Taylor, B. and M.J. Griffin. 1981. The role and relative importance of different ant species in the dissemination of black pod disease in cocoa, p. 114-131. In: P.H. Gregory and A.C. Madison (eds.). Epidemiology of Phytophthora on cocoa in Nigeria. Phytopathol. Paper no. 25, Comm. Mycol. Inst., Kew.

Tuite, J. (ed.) 1969. Plant physiological methods, fungi and bacteria. Burgess Publishing, Minneapolis, Minn. p. 37.

Turner, G.J. 1964. Transmission by snails of the species Phytophthora which causes foot rot of Piper nigrum L. in Sarawak. Nature 202:1133.

Turner, G.J. 1972. Isolation of Phytophthora palmivora from ant runs on Piper nigrum. Trans. Br. Mycol. Soc. 59:317-319.

Zentmyer, G.A., L. Jefferson, and C.J. Hickman. 1973. Another species of Phytophthora on avocado in California. Calif. Avocado Soc. Yearbook 56:125-129.

Zentmyer, G.A., L. Jefferson, C.J. Hickman, and Y. Chang-Ho. 1974. Studies of Phytophthora citricola, isolated from Persea americana. Mycologia 66:830-845. 